\title{
Thrombin Peptide TP508 Stimulates Rapid Nitric Oxide Production in Human Endothelial Cells
}

\author{
Barbara Olszewska-Pazdrak Audrey Hart-VanTassell Darrell H. Carney \\ Therapeutic Peptide Development Laboratory, Department of Biochemistry and Molecular Biology, \\ University of Texas Medical Branch, Galveston, Tex., USA
}

\section{Key Words}

Nitric oxide · Thrombin • Angiogenesis • Wound healing • Vascular endothelial growth factor

\begin{abstract}
TP508, a 23-amino-acid peptide representing a portion of human thrombin, promotes tissue revascularization and repair. The molecular mechanisms of TP508 action, however, remain unclear. Nitric oxide (NO) plays a crucial role in regulation of angiogenesis and wound healing. We, therefore, investigated TP508 effects on NO production in human endothelial cells. TP508 stimulated a rapid, dose-dependent, 2- to 4 -fold increase in NO production. TP508 induced NO release as early as $5 \mathrm{~min}$. Continued exposure to TP508 for 1-24 h increased NO concentrations over controls by $100.5 \pm 9.6$ and $463.3 \pm 24.2 \mathrm{nM}$, respectively. These levels of NO release were similar to those produced in response to vascular endothelial growth factor (VEGF). TP508- and VEGF-induced $\mathrm{NO}$ production was decreased by inhibitors of $\mathrm{PI}-3 \mathrm{~K}$ (LY294002) and Src (PP2). TP508 stimulated early transient phosphorylation of Src and Akt. In contrast to VEGF, TP508 stimulation of NO release was inhibited by PKC inhibitor (Go6976) and was independent of intracellular calcium mobilization. These results demonstrate that TP508 and VEGF stimulate NO production to similar levels but through distinct pathways. This study provides new insights into the ini-
\end{abstract}

tial molecular mechanisms by which TP508 may stimulate diverse cellular effects leading to tissue revascularization and wound healing.

Copyright $\odot 2009$ S. Karger AG, Basel

\section{Introduction}

TP508 is a 23-amino-acid synthetic peptide representing residues $508-530$ of human prothrombin. This molecule was originally identified as the receptor-binding domain of $\alpha$-thrombin based on competition for high-affinity $\alpha$-thrombin binding to fibroblasts and enhancement of fibroblast proliferation [1]. In contrast to thrombin, TP508 has no enzymatic activity and does not promote or interfere with blood coagulation [1]. Thus, TP508 has been used to study nonproteolytic effects of thrombin on cells and in various animal models [2-5]. These studies indicate that TP508 exerts its cellular effects by activation of a receptor on cells distinct from the protease-activated receptors (PAR1-4) [6].

Preclinical studies have shown that TP508 accelerates healing of normal dermal full-thickness wounds [7, 8], ischemic dermal wounds [9], fractures in rats [10], segmental bone defects [11], distraction osteogenesis defects [12] and high-impact fractures involving bone and soft tissue [13]. Based on these results, TP508 is now being evalu- 
ated in clinical trials for treatment of diabetic foot ulcers $[14,15]$ and repair of distal radius fractures [15-17].

Effective wound repair requires growth factor-stimulated angiogenesis [18]. Angiogenesis, the process of new blood vessel formation from preexisting ones, is comprised of several discrete steps including dissociation of matrix, endothelial cell migration, proliferation and tube differentiation [19]. TP508 stimulated early revascularization in dermal and bone injury models $[7,8,10,12,13$, 20 ], and stimulated vascular sprouting in ex vivo cultures of microvessel fragments [21]. Thus, TP508 effects on tissue repair appear to be linked to its stimulation of angiogenesis.

Nitric oxide (NO) has been shown to be a crucial signaling molecule in the regulation of angiogenesis. Endothelium-derived NO produced by endothelial NO synthase (eNOS) plays a significant role in vascular endothelial growth factor (VEGF)-induced angiogenesis in vivo [22] and in vitro $[23,24]$. In addition, angiogenesis was significantly attenuated in eNOS-deficient mice and was not improved by administration of VEGF, suggesting that both eNOS activation and NO production are required for VEGF-stimulated angiogenesis [25].

Other studies have demonstrated the involvement of NO in wound healing [26, 27]. For example, eNOS-deficient mice show impaired wound healing [28], while NO produced locally using NO donor molecules or eNOS gene therapy accelerates tissue repair $[29,30]$. In addition, treatment of diabetic wounds with $\mathrm{L}$-arginine to increase NO production enhances healing both in animal models [31] and in diabetic foot ulcers [32].

We recently reported that in a pig model of chronic myocardial ischemia, TP508 restored myocardial function, endothelial responsiveness to NO-dependent vasodilators and microvessel NO production [33]. In addition, long-term $(24 \mathrm{~h})$ treatment of human coronary artery endothelial cells (HCAECs) with TP508 also increased NO production [33]. These studies show long-term effects of TP508 that may involve the induction of VEGF or other angiogenic cytokines. More recently, systemic infusion of TP508 was shown to decrease infarct size, improve NOdependent microvascular function, and decrease apoptosis in normal and hypercholesterolemic pig models of acute myocardial ischemia-reperfusion injury [34, 35]. Because NO has been reported to have cardioprotective effects [36], these effects of TP508 could also involve NO production.

To understand the initial molecular mechanisms by which TP508 promotes angiogenesis, tissue repair and myocardial protection, we have examined the direct ef- fects of TP508 on early NO production in human endothelial cells. Our results demonstrate that TP508 stimulates rapid NO production in endothelial cells and that the levels of TP508-stimulated NO production are similar to the levels of NO produced in response to VEGF. Results also show that TP508 and VEGF stimulate NO production by distinct signaling pathways. In contrast to previous studies, these results demonstrate direct early effects of TP508 on human endothelial cells and provide new insights into the mechanism by which TP508 stimulates tissue repair.

\section{Materials and Methods}

\section{Reagents}

Thrombin peptide TP508 (AGYKPDEGKRGDACEGDSGGPFV, rusalatide acetate or Chrysalin ${ }^{\circledR}$, CAS No. 87455-82-6) was synthesized and purified by American Peptide Company (Sunnyvale, Calif., USA). VEGF165 was purchased from R\&D System (Minneapolis, Minn., USA). Calcium ionophore A23187 and kinase inhibitors LY294002, PP2, PD98059 and Go6976 were purchased from Calbiochem (San Diego, Calif., USA). N-nitro-L-arginine methyl ester (L-NAME), L-arginine, $\mathrm{NaNO}_{2}$ and $\mathrm{NaI}$ were purchased from Sigma (St. Louis, Mo., USA).

\section{Endothelial Cell Culture}

HCAECs and bovine aortic endothelial cells (BAECs) were purchased from Lonza (Walkersville, Md., USA). Human umbilical vein endothelial cells (HUVECs) were purchased from BD Bioscience (San Jose, Calif., USA). Cells were cultured in endothelial growth medium (EGM) which is endothelial cell basal medium (EBM) supplemented with 5\% fetal bovine serum and growth factors SingleQuots ${ }^{\mathrm{TM}}$ (Clonetics, San Diego, Calif., USA) in $5 \% \mathrm{CO}_{2}$ at $37^{\circ} \mathrm{C}$. Cells between passages 4 and 7 were used for the experiments. HCAECs obtained from two different donors were tested in these studies.

NO Assay

Cells were plated in 24-well plates at a density of 50,000/well and grown in EGM until 2 days after confluency. The medium was replaced with EBM containing $200 \mu \mathrm{M}$ L-arginine and cells were stimulated with TP508 $(20 \mu \mathrm{M})$ or VEGF $(2.5 \mathrm{nM})$ or calcium ionophore A23187 $(1 \mu \mathrm{M})$ for $1 \mathrm{~h}$ or indicated times. In some experiments, cells were pretreated with the specific kinase inhibitors L-NAME $(100 \mu \mathrm{M})$, LY294002 $(50 \mu \mathrm{M})$, PP2 (10 $\mu \mathrm{M})$, PD98059 $(50 \mu \mathrm{M})$, or Go6976 (100 $\mathrm{nM})$ for $45 \mathrm{~min}$ before stimulation. Inhibitor concentrations used have previously shown selective kinase inhibition in endothelial cells $[23,37,38]$. Supernatants were collected and analyzed for total nitrite, a stable breakdown product of NO in aqueous solutions, using a chemiluminescence NO analyzer (Model 270B; Sievers Instruments, Boulder, Colo., USA) as previously described [39]. Briefly, $100 \mu \mathrm{l}$ of sample was placed in a reaction chamber containing a mixture of sodium iodide in glacial acetic acid to reduce nitrite to $\mathrm{NO}$ and allow the liberation of NO gas from the aqueous mixture. The analyzer was calibrated for each experiment using a sodium nitrite standard curve. NO 
Fig. 1. TP508 stimulates rapid NO production in different primary endothelial cells. a HCAECs, HUVECs and BAECs were stimulated with TP508 $(20 \mu \mathrm{M})$ or VEGF $(2.5 \mathrm{nM})$ for $1 \mathrm{~h}$. NO released into supernatants was determined by $\mathrm{NO}$ analyzer. ${ }^{\mathrm{a}} \mathrm{p}<0.01$ compared to control $(\mathrm{n}=4)$. b Effect of NO synthase inhibitor L-NAME on TP508-induced NO production. HCAECs were pretreated with L-NAME $(100 \mu \mathrm{M})$ for $45 \mathrm{~min}$ before stimulation with TP508 $(20 \mu \mathrm{M})$ for $1 \mathrm{~h}$. NO released into the supernatants was determined by NO analyzer. ${ }^{a} \mathrm{p}<0.01$ compared to control; ${ }^{\mathrm{b}} \mathrm{p}<0.01$ compared to TP508 $(\mathrm{n}=4)$.

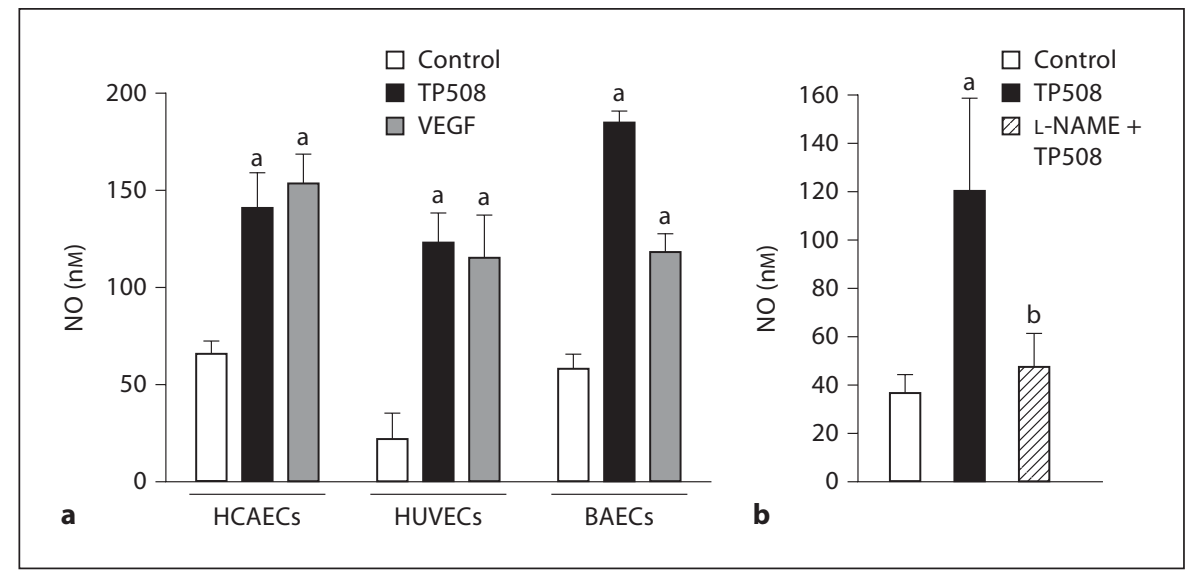

concentration in the EBM containing L-arginine was used as a background value and was subtracted from sample values to determine the amount of NO released from cells.

\section{Western Blot Analysis}

Two-day postconfluent cultures of HCAECs were treated with TP508 $(20 \mu \mathrm{M})$ for indicated times. Cells were solubilized in lysis buffer (150 mM NaCl, 50 mM HEPES, pH 7.4, 1 mM EGTA, 1 mM $\mathrm{Na}_{3} \mathrm{VO}_{4}, 10 \mathrm{~mm} \mathrm{NaF}, 1 \mathrm{~mm}$ phenylmethylsulfonyl fluoride, $5 \%$ glycerol, 1\% Triton X-100) containing a protease inhibitor mixture (Complete, Roche Diagnostics, Indianapolis, Ind., USA). Cell lysates were subjected to SDS-PAGE and transferred to nitrocellulose membranes $(0.2 \mu \mathrm{m}$, Invitrogen, Carlsbad, Calif., USA). Membranes were incubated overnight at $4^{\circ} \mathrm{C}$ with primary antibodies against phospho-Src family (Y416) and phospho-Akt (S473) (Cell Signaling Technology, Beverly, Mass., USA). After stripping, blots were reprobed with Src or Akt antibodies (Cell Signaling Technology). Immunoblots were developed using Immobilon Western Detection Reagents (Millipore Corporation, Billerica, Mass., USA).

\section{Calcium Assay}

Changes in intracellular calcium levels were determined using the Fluo-4 NW Calcium Assay Kit (Molecular Probes, Eugene, Oreg., USA) according to the manufacturer's instructions. HCAECs were grown on 96-well plates until 2 days after confluency in EGM. Cells were incubated with $100 \mu \mathrm{l}$ of the Fluo-4 NW dye loading solution at $37^{\circ} \mathrm{C}$ for $30 \mathrm{~min}$, then at room temperature for an additional $30 \mathrm{~min}$. Cells were stimulated with TP508 (20 $\mu \mathrm{M})$ or VEGF (2.5 nM) or calcium ionophore A23187 (1 $\mu \mathrm{M})$, and fluorescence intensity was measured at indicated times using a Synergy HT fluorescence reader (BioTek, Winooski, Vt., USA) with excitation at $494 \mathrm{~nm}$ and emission at $516 \mathrm{~nm}$. Baseline fluorescence measured in control nonstimulated cells was subtracted from the fluorescence values obtained after the indicated treatments. Each experiment was performed in triplicate.

\section{Statistical Analysis}

Data are presented as means \pm standard deviation. Statistical analysis was performed using Student's t test. $\mathrm{p}<0.05$ was considered as statistically significant.

TP508 Stimulation of Rapid NO

Production

\section{Results}

TP508 Stimulates NO Production in Endothelial Cells

To determine initial mechanisms by which TP508 promotes angiogenesis and tissue protection, we examined the effect of TP508 on early NO production in endothelial cells. Stimulation of HCAECs with TP508 for $1 \mathrm{~h}$ resulted in an $\sim 2.5$-fold increase in the level of $\mathrm{NO}$ in supernatants compared to control cells (153.5 \pm 15.3 vs. $65.3 \pm 7.0 \mathrm{nM}$ ) (fig. 1a). This effect was not limited to HCAECs. Stimulation of HUVECs and BAECs with TP508 also increased NO production $\sim 4$-fold and $\sim 3$ fold compared to control cells, respectively (fig. 1a). Interestingly, the levels of NO production stimulated by TP508 were comparable to the levels of VEGF-induced NO release from these same cells (fig. 1a). Pretreatment of HCAECs with the NO synthase (NOS) inhibitor, LNAME effectively blocked TP508-stimulated NO production (fig. 1b). Thus, confirming that the increased levels of NO production, as measured from total nitrite accumulation in the medium, resulted from activation of NOS.

TP508 induced NO production by endothelial cells in a dose-dependent manner in both HCAECs and BAECs (fig. 2). Stimulation of cells with $0.4 \mu \mathrm{M}$ TP508 was sufficient to significantly increase NO production in both HCAECs $(135.3 \pm 16.2$ vs. $74.1 \pm 12.4 \mathrm{nM})$ and in BAECs $(62.0 \pm 8.8$ vs. $24.1 \pm 12.2 \mathrm{nM})$ compared to control cells. The maximal level of $\mathrm{NO}$ production was obtained from cells stimulated with 20-40 $\mu \mathrm{M}$ TP508. There was no significant difference between doses of 20-40 $\mu \mathrm{M}$ TP508 in human ( $317.75 \pm 32.2$ vs. $322.4 \pm 25.2 \mathrm{nM})$ and bovine $(224.0 \pm 20.6$ vs. $234.4 \pm 26.8 \mathrm{nM})$ endothelial cells (fig. 2). Thus, $20 \mu \mathrm{M}$ TP508 ( $50 \mu \mathrm{g} / \mathrm{ml})$ was consid- 


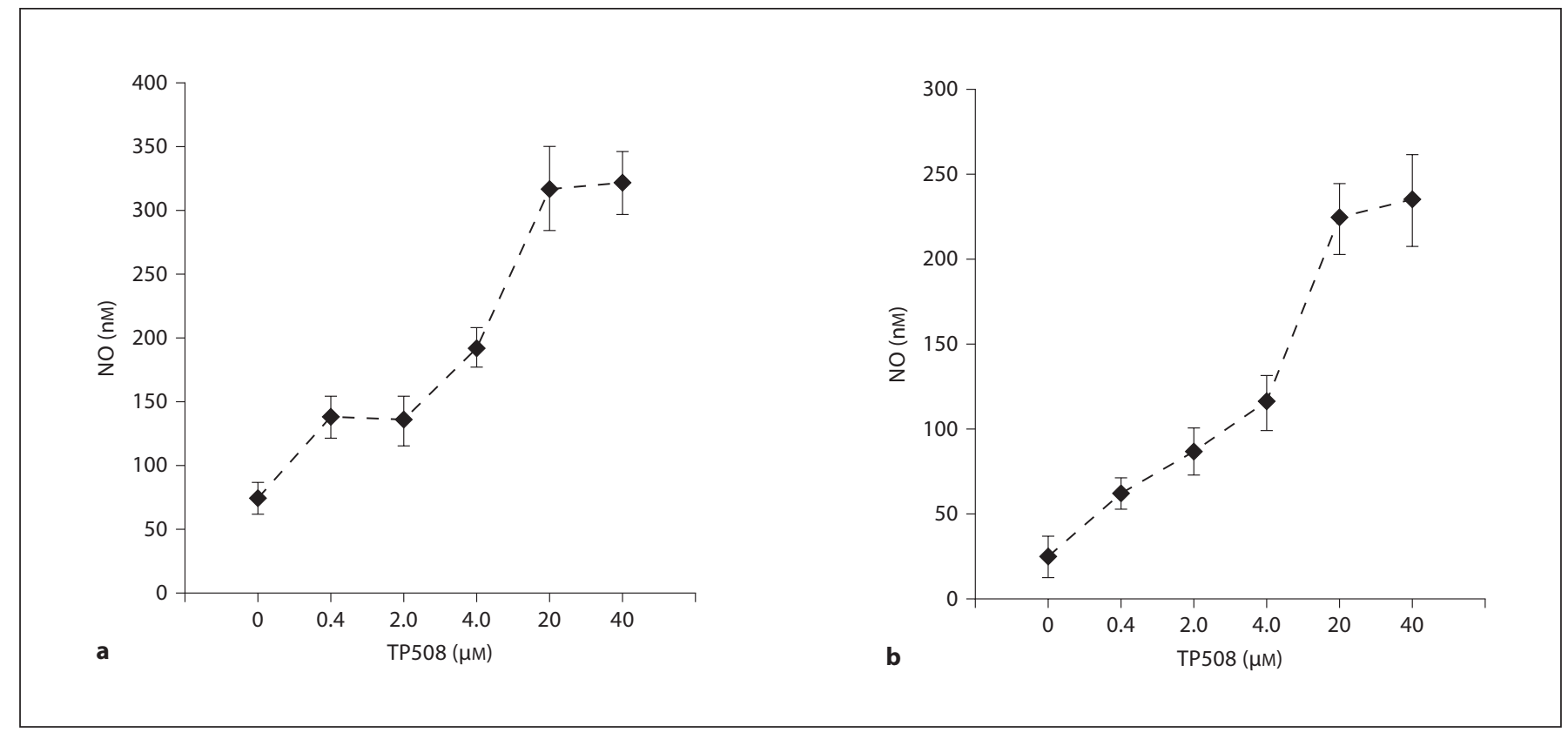

Fig. 2. Dose response of TP508-stimulated NO production. HCAECs (a) and BAECs (b) were incubated with the indicated doses of TP508 for $1 \mathrm{~h}$. NO released into supernatants was determined by NO analyzer. Data are presented as means $\pm \mathrm{SD}(\mathrm{n}=4)$.

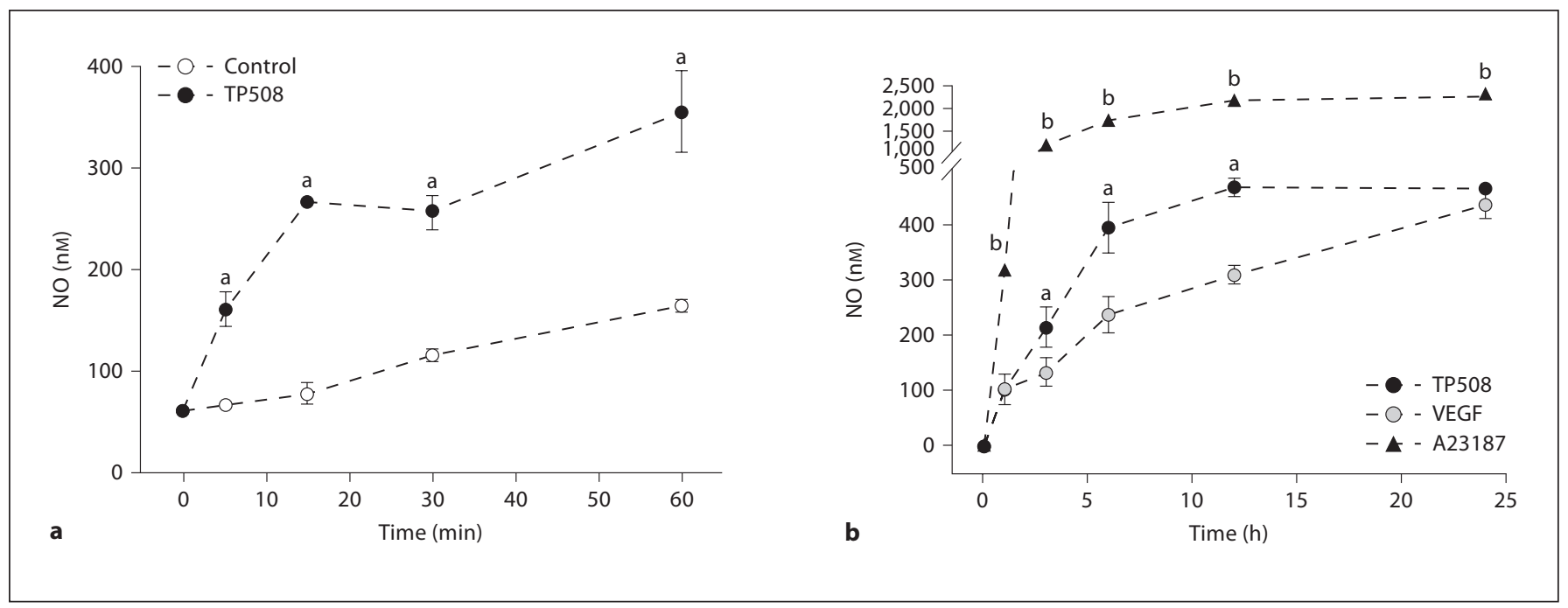

Fig. 3. Time course of TP508-stimulated NO production. a BAECs were treated with or without TP508 $(20 \mu \mathrm{M})$ for 5, 15, 30 and $60 \mathrm{~min}$. After the indicated times, the supernatants were collected from control and TP508stimulated cells, and NO released into the supernatants was determined by NO analyzer. ${ }^{\mathrm{a}} \mathrm{p}<0.01$, compared to control $(\mathrm{n}=4)$. b BAEC were incubated with or without TP508 $(20 \mu \mathrm{M})$, VEGF $(2.5 \mathrm{nM})$, or calcium ionophore A23187 $(1 \mu \mathrm{M})$. After 1, 3, 6, 12 and $24 \mathrm{~h}$ stimulation, the supernatants were collected and NO concentration in the samples was determined by NO analyzer. Data are presented as NO concentrations over control values for each time point. ${ }^{\mathrm{a}} \mathrm{p}<0.01$, compared to VEGF; ${ }^{\mathrm{b}} \mathrm{p}<0.01$, compared to TP508 or VEGF $(\mathrm{n}=4)$. 


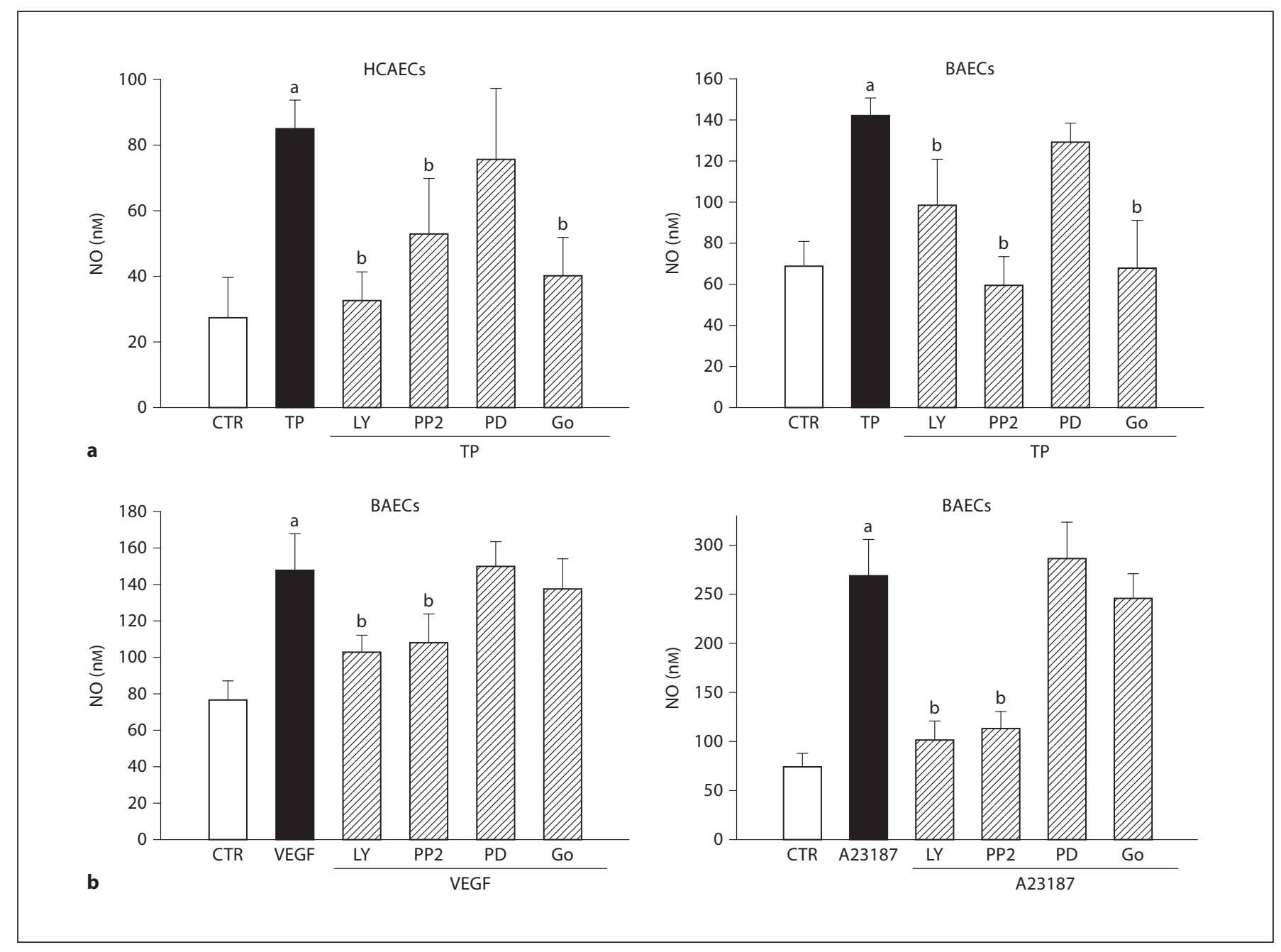

Fig. 4. Effect of specific kinase inhibitors on TP508-stimulated NO production. a HCAECs and BAECs were preincubated with specific kinase inhibitors LY294002 (LY), PP2 (PP2), PD98059 (PD) and Go6976 (Go) for 45 min before stimulation with TP508 $(20 \mu \mathrm{M})(\mathrm{TP})$ for $1 \mathrm{~h}$. b BAEC were preincubated with specific kinase inhibitors LY294002 (LY), PP2 (PP2), PD98059 (PD) and Go6976 (Go) for $45 \mathrm{~min}$. Cells were stimulated with or without VEGF $(2.5 \mathrm{nM})$ or calcium ionophore A23187 $(1 \mu \mathrm{M})$ for $1 \mathrm{~h}$. NO concentration in samples was determined by NO analyzer. ${ }^{\mathrm{a}} \mathrm{p}<0.01$, compared to control (CTR); ${ }^{\mathrm{b}} \mathrm{p}<0.01$, compared to TP or Ca or VEGF without inhibitors $(n=4)$.

ered the optimal dose for these cells and has been used throughout these experiments. We also determined that $2.5 \mathrm{nM}(\sim 50 \mathrm{ng} / \mathrm{ml})$ was the optimal dose for VEGFstimulated production of $\mathrm{NO}$ in these same cells (data not shown).

Our studies showed that TP508 stimulated rapid NO release from endothelial cells within 5-10 min, reached a maximum level over controls by $15 \mathrm{~min}$ and then remained approximately the same during a 1-hour time course (fig. $3 \mathrm{a}$ ). This rapid stimulation suggests activa- tion of constitutively expressed eNOS. Continued exposure of cells to TP508 for 1, 3, 6, 12 and $24 \mathrm{~h}$ resulted in increased NO concentrations (over control levels for each time point) by $100.5 \pm 9.0,214.8 \pm 37.8,394.5 \pm 45.5$, $466.5 \pm 16.7$ and $463.3 \pm 24.2 \mathrm{nM}$ (fig. 3b). The levels of VEGF-stimulated NO production over this time course were similar to those seen with TP508 at 1 and $24 \mathrm{~h}$ (fig. 3b). Interestingly, at intermediate time points between 3 and $12 \mathrm{~h}$, TP508-stimulated NO production was significantly higher than VEGF-stimulated NO produc- 


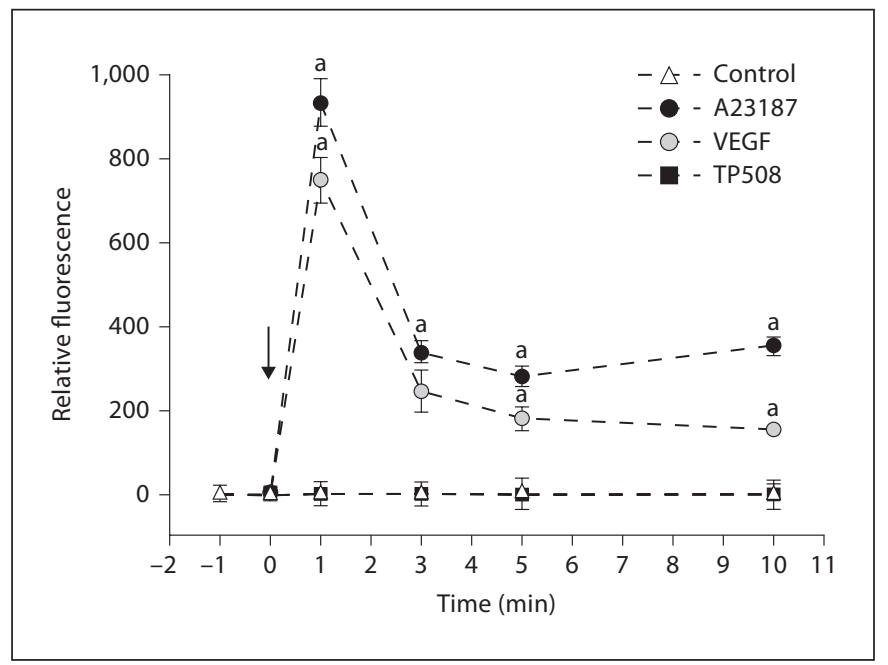

Fig. 5. Effect of TP508 on intracellular calcium concentration. HCAECs were loaded with Fluo- 4 NW dye and stimulated with TP508 $(20 \mu \mathrm{M})$, VEGF (2.5 nM), or calcium ionophore A23187 $(1 \mu \mathrm{M})$. Changes in intracellular calcium levels were measured by changes in fluorescence intensity of Fluo- 4 dye at the indicated times after treatment. Data are presented as relative fluorescence intensity compared to control cells. ${ }^{a} \mathrm{p}<0.01$, compared to control $(\mathrm{n}=3)$. Arrow indicates time 0 , when factors were added to cells.

tion. In contrast, stimulation with calcium ionophore resulted in much higher $\mathrm{NO}$ production at all time points tested compared to TP508 or VEGF, reaching a maximum of 2,264 $\pm 79 \mathrm{nM}$ at $24 \mathrm{~h}$ (fig. 3b).

\section{Effect of Specific Kinase Inhibitors on}

\section{TP508-Stimulated NO Production}

To investigate potential signaling pathways that might be involved in TP508-induced NO production, cells were pretreated with specific kinase inhibitors for $45 \mathrm{~min}$ before stimulation. In both HCAECs and BAECs, the amount of TP508-stimulated NO production at $1 \mathrm{~h}$ was significantly reduced by inhibitors of PI-3K (LY294002), Src (PP2) and PKC (Go6976) but not by MEK inhibitor (PD98059) (fig. 4a). This suggests the possible involvement of PI-3K, Src and PKC- $\alpha / \beta$ in TP508-induced activation of eNOS. VEGF- and calcium ionophore A23187stimulated NO production was also attenuated by inhibitors of PI-3K (LY294002) and Src (PP2) (fig. 4b). In contrast to TP508, however, the Go6976 inhibitor specific for PKC- $\alpha / \beta$ had no significant effect on VEGF- or calcium ionophore-stimulated NO release (fig. $4 \mathrm{~b}$ ). That the kinase inhibitors showed different patterns of inhibition between TP508-, calcium ionophore- and VEGFstimulated NO release demonstrates the specificity of

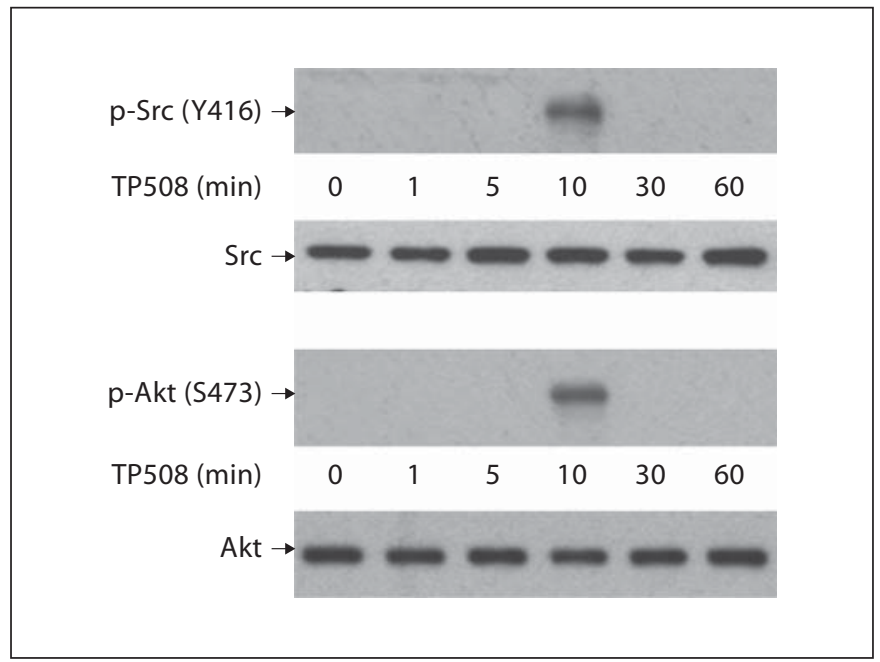

Fig. 6. TP508 activates Src and Akt kinase. HCAECs were stimulated with TP508 $(20 \mu \mathrm{M})$ for the indicated times. Activation of Src or Akt was determined by Western blotting using antibodies specific for phospho-Src family (Y416) or phospho-Akt (S473). Immunoblots were reprobed with antibodies recognizing total Src or Akt. Representative experiments are shown $(n=2)$.

these inhibitors. These kinase inhibitor studies suggest that TP508 and VEGF stimulation of NO production may both involve PI-3K and Src pathways, but that TP508 stimulation may also be dependent on PKC- $\alpha / \beta$ signaling in these cells.

\section{TP508 Does Not Increase Intracellular Calcium}

Previous studies have shown that eNOS activation by VEGF requires intracellular calcium mobilization [37, 40], while insulin, estrogen and shear stress do not [4143]. To determine whether changes in intracellular calcium concentrations were involved in TP508-stimulated NO production, we measured intracellular calcium levels using a Fluo-4 fluorescence calcium indicator. TP508 treatment did not significantly affect intracellular calcium concentrations in HCAECs during 10 min of stimulation (fig. 5). Moreover, we did not observe any significant effect of TP508 on calcium levels during incubation up to $1 \mathrm{~h}$ (data not shown). In contrast, VEGF and calcium ionophore treatment of these cells resulted in a rapid increase in intracellular calcium levels (fig. 5). These same cells were also tested for NO production in parallel experiments which showed that stimulation of these cells by all three factors resulted in increased NO release. These data indicate that TP508-induced stimulation of 
NO production does not require intracellular calcium mobilization. This result demonstrates a significant difference between VEGF and TP508 in the activation of eNOS.

\section{TP508 Induces Transient Activation of Akt and Src Kinase}

Insulin, estrogen and other factors have been reported to stimulate NO production through calcium-independent mechanisms [41-44]. Calcium-independent eNOS activation appears to involve Src phosphorylation of caveolin-1, phosphorylation of Akt and caveolae internalization $[45,46]$. TP508-stimulated NO production was decreased by Src and Akt inhibitors. We therefore evaluated TP508 effects on Src and Akt activation. As shown in figure 6, Western blot analyses with phospho-specific antibodies, recognizing the activated form of Src family kinases (Y416) or activated Akt (S473), showed that TP508 caused a transient phosphorylation of Akt and a Src kinase in HCAECs. Together, these results suggest that TP508 stimulates early NO production through a mechanism that is calcium independent, but that involves activation of Src and Akt.

\section{Discussion}

The present studies were undertaken to determine the direct effect of the nonproteolytic thrombin peptide TP508 on early NO production in primary endothelial cells. TP508 has previously been shown to stimulate tissue revascularization following injury $[7,8,10,12,20]$ and angiogenic sprouting in ex vivo cultures of microvessel fragments [21]. Recent in vivo and long-term culture experiments showed that TP508 reverses endothelial dysfunction and increases NO production in endothelial cells [33]. These studies, however, only investigated longterm effects that may result from TP508-induced upregulation of VEGF or other angiogenic cytokines. It was therefore important to determine whether TP508 directly stimulated early NO production in endothelial cells as a signaling mechanism to promote angiogenesis. Our studies demonstrate for the first time that TP508 stimulates rapid NO release in human endothelial cells. Moreover, the effects of TP508 on NO production in these endothelial cells are comparable to the effects of the wellcharacterized angiogenic factor VEGF.

NO produced by endothelial cells plays an important role in angiogenesis following injury [28]. Moreover, NO production induced by VEGF also significantly contrib- utes to its growth-promoting effect on endothelial cells $[24,47]$. We have shown that TP508 accelerates wound healing in animal models and increases revascularization of injured tissues [7-9]; however, the molecular mechanisms responsible for accelerated tissue repair and revascularization remain unclear. In this study, we showed that TP508 induced NO release during $1 \mathrm{~h}$ treatment in HCAECs, HUVECs and BAECs.

To evaluate the biological significance of these results, we compared the effect of TP508 with the effect of the angiogenic factor VEGF. These studies demonstrated that TP508 stimulated NO production to levels similar to those caused by VEGF stimulation. TP508 stimulated rapid NO release, as early as $5 \mathrm{~min}$ after treatment, with continued $\mathrm{NO}$ accumulation during exposure up to $24 \mathrm{~h}$. NO levels measured in VEGF-treated cells were similar to NO levels in TP508-treated cells after 1 and $24 \mathrm{~h}$ incubation.

As an initial step to explore signaling pathways involved in TP508-induced NO production, we pretreated cells for 45 min with specific kinase inhibitors and measured NO production after $1 \mathrm{~h}$ stimulation with TP508, VEGF, or calcium ionophore A23187. We found that TP508-stimulated NO production was significantly decreased by inhibitors of PI-3K (LY294002), PKC (Go6976) and Src (PP2) but not by MEK inhibitor (PD98059). This suggested involvement of PI-3K, PKC- $\alpha / \beta$ and Src in activation of eNOS by TP508. VEGF- and calcium ionophore-stimulated NO production was attenuated by inhibitors of PI-3K (LY294002) and Src (PP2), but not by the MEK inhibitor (PD98059) or the inhibitor of PKC- $\alpha / \beta$ (Go6976). Thus, these results suggest that eNOS activation by TP508 involves activation of PKC- $\alpha / \beta$, while activation by VEGF or calcium ionophore does not. The lack of inhibition of VEGF stimulation by Go6976 is consistent with a recent study showing that siRNA-mediated downregulation of PKC- $\varepsilon$ but not PKC- $\alpha$ abrogated VEGF-stimulated eNOS activity in BAECs [48]. The Src inhibitor (PP2) significantly prevented NO release in response to TP508, calcium ionophore and VEGF. This result is consistent with three potential roles played by Src in the activation of eNOS under different conditions. First, it has been shown that Src-mediated phosphorylation of Hsp90 is required for VEGF-stimulated NO production [49]. Second, tyrosine phosphorylation by Src can activate eNOS [50]. Third, Src phosphorylation of PI$3 \mathrm{~K}$ and Akt activate eNOS in response to estrogen [38]. The PI-3K inhibitor (LY294002) also significantly prevented NO release in response to TP508, calcium ionophore and VEGF. A number of studies have shown that 
phosphorylation of Akt, which is activated by the PI-3K pathway, is required for VEGF-stimulated eNOS activation and NO production $[37,51,52]$.

Since eNOS activity can be regulated by $\mathrm{Ca} / \mathrm{calmodu}$ lin interaction $[40,53]$ and eNOS activation by VEGF requires intracellular calcium mobilization [40], we determined the effects of TP508 on intracellular calcium concentration in HCAECs. We found that TP508 treatment did not increase intracellular calcium levels. In contrast, stimulation of cells with VEGF or calcium ionophore caused rapid increases in calcium concentrations. Parallel experiments using the same cells confirmed that VEGF, TP508 and calcium ionophore all increased NO release. These results demonstrate that TP508-induced NO production does not require intracellular calcium mobilization. Calcium-independent stimulation of NO production has previously been reported in endothelial cells stimulated by insulin, estrogen and shear stress [4144]. Such a calcium-insensitive eNOS activation has recently been linked to Src phosphorylation of caveolin-1, phosphorylation of Akt and eNOS and to caveolae internalization $[45,46]$. Since our inhibitor studies showed that TP508-induced activation of NO production was decreased by Src and Akt inhibitors, it may be possible that TP508 activates eNOS through this Src-mediated calcium-insensitive pathway.

Evaluation of TP508 effects on Src and Akt activation showed that TP508 stimulated early transient phosphorylation of both Src and Akt. TP508 has also been shown to stimulate phosphorylation of Akt in adipose tissue-derived stem cells [54]. Moreover, TP508 stimulation of proliferation in these stem cells was inhibited by the same PI-3K inhibitor (LY294002) that inhibited TP508-stimulated NO production in our present studies. As described above, Src and Akt phosphorylations appear to be involved in a number of different pathways that lead to activation of eNOS.

These results suggest that activation of eNOS by TP 508 and VEGF both involve the activation of PI-3K/Akt and Src, but TP508 and VEGF activation pathways are distinct with respect to involvement of PKC and calcium mobilization. Studies are underway to more fully elucidate the signaling pathways involved in TP508-stimulated NO production.

The TP508 peptide was originally identified as a fibroblast-receptor-binding domain peptide [1]. This nonproteolytic peptide, however, activated cellular responses that were distinct from those stimulated by thrombin or the protease-activated receptor-1 (PAR1)-activating peptide SFLLRN [3]. Moreover, downregulation of PAR1 in- hibited cytokine production in monocytes stimulated by thrombin or SFLLRN, but not cytokine production stimulated by TP508 [5]. TP508, therefore, appears to stimulate its cellular signals by mechanisms that do not involve PAR1 activation. These results led to the hypothesis that nonproteolytic peptides produced at the site of injury by thrombin degradation stimulate non-PARs to activate tissue repair [6]. This hypothesis has been supported by recent photoaffinity cross-linking studies with radiolabeled TP508 which show specific binding of TP508 to a molecule not corresponding in size to that of PARs [Bergmann and Carney, unpubl.].

Although we did not directly compare thrombin and TP508 stimulation of NO production in the present study, our results support the concept that TP508 and thrombin activate different signaling pathways. Previous studies have shown that thrombin stimulates NO production through a mechanism that is independent of PI-3K/Akt activation but dependent on calcium mobilization and activation of PKC- $\delta[55,56]$. Our results showed that TP508 stimulation of early NO production was calciumindependent. Moreover, inhibitor studies suggest that TP508 stimulation may be dependent on activation of PI$3 \mathrm{~K}$ and PKC- $\alpha / \beta$. Thus, activation of eNOS by TP508 appears to differ from thrombin activation in respect to requirement for calcium, activation of PI-3K/Akt and possibly different subtypes of PKC. Additional studies are underway to better define early signaling events leading to stimulation of NO production by TP508 and to determine how cell signaling by TP508 differs from that of thrombin and PAR-activating peptides.

It seems likely that many of the wound-healing effects of TP508, including its effect on diabetic foot ulcers [14, 15], may be related to TP508 stimulation of NO production. Results from the initial double-blind placebo-controlled phase 1/2 clinical trial using TP508 for treatment of diabetic foot ulcers showed that twice weekly topical application of TP508 to diabetic foot ulcers resulted in $70 \%$ complete closure by 20 weeks compared to a $32 \%$ closure in those treated with placebo [14]. Moreover, large ulcers on the heel of feet showed $87 \%$ closure (6 of 7) with TP508 treatment and $0 \%$ closure ( 0 of 6 ) with placebo treatment [14]. This dramatic healing effect suggests that TP508 may stimulate a number of different cellular effects to convert the chronic nonhealing environment to one that actively promotes healing [15]. NO produced locally by topical treatment of TP508 may directly promote chronic ulcer healing since it is required for angiogenesis [22-24], recruitment of progenitor cells $[57,58]$ and regulation of metalloproteinase expression [59,60]. Indeed, 
decreased NO production appears to be a major impediment to chronic wound healing [61]. Moreover, treatment of diabetic wounds with L-arginine to increase NO production enhanced healing both in animal models [31] and in diabetic foot ulcers [32].

Although NO-releasing hydrogels alone have been shown to accelerate tissue repair [62], high levels of NO such as those that are produced by induction of inducible NOS (iNOS) have been shown to inhibit endothelial cell proliferation [63], tube formation [64] and wound healing $[65,66]$. Our studies showed that the levels of NO produced by TP508 stimulation at early time points and after $24 \mathrm{~h}$ were comparable to those seen with VEGF treatment. Thus, the stimulation of NO by TP508 is within a range that would be expected to stimulate angiogenesis.

The rapid stimulation of NO production by TP508 in endothelial cells observed in this study may be especially relevant as a mechanism to explain the recently demonstrated myocardial protective effects of TP508 in ischemia-reperfusion injury in normal and hypercholesterolemic pigs $[34,35]$. In these studies, TP508 perfusion decreased infarct size, improved NO-dependent microvascular function and decreased apoptosis. Previous studies have shown that NO produced by endothelial cells in response to insulin has similar cardioprotective effects [36]. Thus, TP508-stimulated endothelial cell NO production may explain the effects of this peptide on both tissue repair and myocardial protection.

In conclusion, our results demonstrate that TP508 stimulates rapid NO production in a dose-dependent manner in human and bovine endothelial cells. This effect of TP508 is comparable to the effect of VEGF, but unlike VEGF, early TP508 stimulation of NO does not require intracellular calcium mobilization. These studies provide a molecular mechanism by which nonproteolytic thrombin peptides such as TP508 may orchestrate a number of different cellular events leading to tissue revascularization, acceleration of wound healing and myocardial protection.

\section{Acknowledgements}

The authors would like to acknowledge research funding from UTMB Endowment Funds to D.H.C. OrthoLogic Corp., now operating as Capstone Therapeutics of Tempe AZ (NASAQ; CAPS), owns worldwide rights to thrombin peptide TP508 (Chrysalin ${ }^{\circledR}$, rusalatide acetate). D.H.C. discloses ownership of stock in OrthoLogic. Potential conflicts of interest are managed by The University of Texas Medical Branch Conflict of Interests Committee.

\section{References}

1 Glenn KC, Frost GH, Bergmann JS, Carney DH: Synthetic peptides bind to high-affinity thrombin receptors and modulate thrombin mitogenesis. Peptide Res 1988;1:65-73.

-2 Carney DH, Herbosa GJ, Stiernberg J, Bergmann JS, Gordon EA, Scott D, Fenton JWI: Double-signal hypothesis for thrombin initiation of cell proliferation. Semin Thromb Hemost 1986;12:231-240.

-3 Sower LE, Payne DA, Meyers R, Carney DH: Thrombin peptide, TP508, induces differential gene expression in fibroblasts through a nonproteolytic activation pathway. Exp Cell Res 1999;247:422-431.

-4 Stiernberg J, Redin WR, Warner WS, Carney $\mathrm{DH}$ : The role of thrombin and thrombin receptor activating peptide (TRAP-508) in initiation of tissue repair. Thromb Haemost 1993;70:158-162.

$\checkmark 5$ Naldini A, Carraro F, Baldari CT, Paccani SR, Bernini C, Keherly MJ, Carney DH: The thrombin peptide, TP508, enhances cytokine release and activates signaling events. Peptides 2004;25:1917-1926.
6 Olszewska-Pazdrak B, Bergmann JS, Fuller GM, Carney DH: The role of thrombin and thrombin peptides in wound healing and tissue repair; in Maragoudakis ME, Tsopanoglou NE (eds): Thrombin Physiology and Disease. New York, Springer, 2009, pp 115 132.

7 Carney DH, Mann R, Redin WR, Pernia SD, Berry D, Heggers JP, Hayward PG, Robson MC, Christie J, Annable C, Fenton JWI, Glenn KC: Enhancement of incisional wound healing and neovascularization in normal rats by thrombin and synthetic thrombin receptor-activating peptides. J Clin Invest 1992;89:1469-1477.

-8 Stiernberg J, Norfleet AM, Redin WR, Warner WS, Fritz RR, Carney DH: Acceleration of full-thickness wound healing in normal rats by the synthetic thrombin peptide, TP508. Wound Repair Regen 2000;8:204215.

\$9 Norfleet AM, Huang Y, Sower LE, Redin WR, Fritz RR, Carney DH: Thrombin peptide TP508 accelerates closure of dermal excisions in animal tissue with surgically induced ischemia. Wound Repair Regen 2000; 8:517-529.
10 Wang H, Li X, Tomin E, Doty SB, Lane JM, Carney DH, Ryaby JT: Thrombin peptide (TP508) promotes fracture repair by up-regulating inflammatory mediators, early growth factors, and increasing angiogenesis. J Orthop Res 2005;23:671-679.

-11 Sheller MR, Crowther RS, Kinney JH, Yang J, Di Jorio S, Breunig T, Carney DH, Ryaby JTJ: Repair of rabbit segmental defects with the thrombin peptide, TP508. J Orthop Res 2004;22:1094-1099.

$>12$ Li G, Ryaby JT, Carney DH, Wang H: Bone formation is enhanced by thrombin-related peptide TP508 during distraction osteogenesis. J Orthop Res 2005;23:196-202.

13 Hanratty BM, Ryaby JT, Pan XH, Li G: Thrombin related peptide TP508 promoted fracture repair in a mouse high energy fracture model. J Orthop Surg Res 2009;4:1.

14 Fife C, Mader JT, Stone J, Brill L, Satterfield K, Norfleet A, Zwernemann A, Ryaby JT, Carney DH: Thrombin peptide Chrysalin ${ }^{\circledR}$ stimulates healing of diabetic foot ulcers in a placebo-controlled phase I/II study. Wound Repair Regen 2007;15:23-34. 
15 Carney DH, Olszewska-Pazdrak B: Could rusalatide acetate be the future drug of choice for diabetic foot ulcers and fracture repair? Expert Opin Pharmacother 2008;9: 2717-2726.

16 Ryaby JT, Sheller MR, Levine BP, Bramlet DG, Ladd AL, Carney DH: Thrombin peptide TP508 stimulates cellular events leading to angiogenesis, revascularization, and repair of dermal and musculoskeletal tissues. J Bone Joint Surg Am 2006;88 Suppl 3:132139.

17 Ladd AL, Shin AYS, Bramlet DG, Wolfe SW, Ryaby JT: Phase 3 acceleration of distal radius fracture healing with a thrombin receptor binding peptide. OrthoLogiccom Web Site 2007

-18 Arnold F, West DC: Angiogenesis in wound healing. Pharmacol Ther 1991;52:407-422.

$>19$ Folkman J: Angiogenesis: initiation and control. Ann NY Acad Sci 1982;401:212-224.

20 Norfleet AM, Bergmann JS, Carney DH: Thrombin peptide, TP508, stimulates angiogenic responses in animal models of dermal wound healing, in chick chorioallantoic membranes, and in cultured human aortic and microvascular endothelial cells. Gen Pharmacol 2000;35:249-254.

-21 Vartanian KB, Chen HY, Kennedy J, Beck SK, Ryaby JT, Wang H, Hoying JB: The nonproteolytically active thrombin peptide TP508 stimulates angiogenic sprouting. J Cell Physiol 2006;206:175-180.

-22 Fukumura D, Gohongi T, Kadambi A, Izumi Y, Ang J, Yun CO, Buerk DG, Huang PL, Jain RK: Predominant role of endothelial nitric oxide synthase in vascular endothelial growth factor-induced angiogenesis and vascular permeability. Proc Natl Acad Sci USA 2001;98:2604-2609.

-23 Papapetropoulos A, Garcia-Cardena G, Madri JA, Sessa WC: Nitric oxide production contributes to the angiogenic properties of vascular endothelial growth factor in human endothelial cells. J Clin Invest 1997;100: 3131-3139.

24 Morbidelli L, Chang CH, Douglas JG, Granger HJ, Ledda F, Ziche M: Nitric oxide mediates mitogenic effect of vegf on coronary venular endothelium. Am J Physiol 1996; 270:H411-H415.

-25 Murohara T, Asahara T, Silver M, Bauters C, Masuda H, Kalka C, Kearney M, Chen D, Symes JF, Fishman MC, Huang PL, Isner JM: Nitric oxide synthase modulates angiogenesis in response to tissue ischemia. J Clin Invest 1998;101:2567-2578.

26 Schaffer MR, Tantry U, Gross SS, Wasserburg HL, Barbul A: Nitric oxide regulates wound healing. J Surg Res 1996;63:237-240.

$\checkmark 27$ Luo JD, Chen AF: Nitric oxide: a newly discovered function on wound healing. Acta Pharmacol Sin 2005;26:259-264.
28 Lee PC, Salyapongse AN, Bragdon GA, Shears LL 2nd, Watkins SC, Edington HD, Billiar TR: Impaired wound healing and angiogenesis in eNOS-deficient mice. Am J Physiol 1999;277:H1600-H1608.

29 Diwan AD, Wang MX, Jang D, Zhu W, Murrell GA: Nitric oxide modulates fracture healing. J Bone Miner Res 2000;15:342-351.

30 Breen AM, Dockery P, O’Brien T, Pandit AS: The use of therapeutic gene eNOS delivered via a fibrin scaffold enhances wound healing in a compromised wound model. Biomaterials 2008;29:3143-3151.

31 Witte MB, Thornton FJ, Tantry U, Barbul A: L-Arginine supplementation enhances diabetic wound healing: involvement of the nitric oxide synthase and arginase pathways. Metabolism 2002;51:1269-1273.

32 Arana V, Paz Y, González A, Méndez V, Méndez JD: Healing of diabetic foot ulcers in Larginine-treated patients. Biomed Pharmacother 2004;58:588-597.

33 Fossum TW, Olszewska-Pazdrak B, Mertens MM, Makarski LA, Miller MW, Hein TW, Kuo L, Clubb F, Fuller GM, Carney DH: TP508 (Chrysalin) reverses endothelial dysfunction and increases perfusion and myocardial function in hearts with chronic ischemia. J Cardiovasc Pharmacol Ther 2008;13: 214-225.

34 Osipov RM, Bianchi C, Clements RT, Feng J, Liu Y, Xu SH, Robich MP, Wagstaff J, Sellke FW: Thrombin fragment (TP508) decreases myocardial infarction and apoptosis after ischemia reperfusion injury. Ann Thorac Surg 2009;87:786-793.

>35 Osipov RM, Robich MP, Feng J, Clements RT, Liu Y, Glazer HP, Wagstaff J, Bianchi C, Sellke FW: Effect of thrombin fragment (TP508) on myocardial ischemia-reperfusion injury in hypercholesterolemic pigs. J Appl Physiol 2009;106:1993-2001.

36 Gao F, Gao E, Yue TL, Ohlstein EH, Lopez BL, Christopher TA, Ma XL: Nitric oxide mediates the antiapoptotic effect of insulin in myocardial ischemia-reperfusion: the roles of PI3-kinase, Akt, and endothelial nitric oxide synthase phosphorylation. Circulation 2002;105:1497-1502.

37 Gélinas DS, Bernatchez PN, Rollin S, Bazan NG, Sirois MG: Immediate and delayed VEGF-mediated no synthesis in endothelial cells: role of PI3K, PKC and PLC pathways. Br J Pharmacol 2002;137:1021-1030.

38 Haynes MP, Li L, Sinha D, Russell KS, Hisamoto K, Baron R, Collinge M, Sessa WC, Bender JR: Src kinase mediates phosphatidylinositol 3-kinase/Akt-dependent rapid endothelial nitric-oxide synthase activation by estrogen. J Biol Chem 2003;278:21182123.

39 Hein TW, Zhang C, Wang W, Chang CI, Thengchaisri N, Kuo L: Ischemia-reperfusion selectively impairs nitric oxide-mediated dilation in coronary arterioles: counteracting role of arginase. FASEB J 2003; 17: 2328-2330.
40 Brouet A, Sonveaux P, Dessy C, Balligand JL, Feron O: Hsp90 ensures the transition from the early $\mathrm{Ca}^{2+}$-dependent to the late phosphorylation-dependent activation of the endothelial nitric-oxide synthase in vascular endothelial growth factor-exposed endothelial cells. J Biol Chem 2001;276:3266332669.

41 Kuchan MJ, Frangos JA: Role of calcium and calmodulin in flow-induced nitric oxide production in endothelial cells. Am J Physiol 1994;266:C628-C636.

42 Caulin-Glaser T, García-Cardeña G, Sarrel P, Sessa WC, Bender JR: $17 \beta$-estradiol regulation of human endothelial cell basal nitric oxide release, independent of cytosolic $\mathrm{Ca}^{2+}$ mobilization. Circ Res 1997;81:885-892.

$\checkmark 43$ Montagnani M, Chen H, Barr VA, Quon MJ: Insulin-stimulated activation of eNOS is independent of $\mathrm{Ca}^{2+}$ but requires phosphorylation by Akt at Ser(1179). J Biol Chem 2001; 276:30392-30398.

44 Boo YC, Sorescu GP, Bauer PM, Fulton D, Kemp BE, Harrison DG, Sessa WC, Jo H: Endothelial no synthase phosphorylated at Ser635 produces NO without requiring intracellular calcium increase. Free Radic Biol Med 2003;35:729-741.

45 Bkaily G, D’Orléans-Juste P, Jacques D: A new paradigm: calcium independent and caveolae internalization dependent release of nitric oxide by the endothelial nitric oxide synthase. Circ Res 2006;99:793-794.

46 Maniatis NA, Brovkovych V, Allen SE, John TA, Shajahan AN, Tiruppathi C, Vogel SM, Skidgel RA, Malik AB, Minshall RD: Novel mechanism of endothelial nitric oxide synthase activation mediated by caveolae internalization in endothelial cells. Circ Res 2006; 99:870-877.

47 Ziche M, Morbidelli L, Choudhuri R, Zhang HT, Donnini S, Granger HJ, Bicknell R: Nitric oxide synthase lies downstream from vascular endothelial growth factor-induced but not basic fibroblast growth factor-induced angiogenesis. J Clin Invest 1997;99: 2625-2634

>48 Rask-Madsen C, King GL: Differential regulation of vegf signaling by PKC- $\alpha$ and PKC- $\varepsilon$ in endothelial cells. Arterioscler Thromb Vasc Biol 2008;28:919-924.

-49 Duval M, Le Boeuf F, Huot J, Gratton JP: Srcmediated phosphorylation of Hsp90 in response to vascular endothelial growth factor (VEGF) is required for VEGF receptor-2 signaling to endothelial NO synthase. Mol Biol Cell 2007;18:4659-4668.

50 Fulton D, Church JE, Ruan L, Li C, Sood SG, Kemp BE, Jennings IG, Venema RC: Src kinase activates endothelial nitric-oxide synthase by phosphorylating Tyr-83. J Biol Chem 2005;280:35943-35952.

51 Dimmeler S, Fleming I, Fisslthaler B, Hermann C, Busse R, Zeiher AM: Activation of nitric oxide synthase in endothelial cells by Akt-dependent phosphorylation. Nature 1999;399:601-605.
Olszewska-Pazdrak/Hart-VanTassell/ Carney 
-52 Brouet A, Sonveaux P, Dessy C, Moniotte S, Balligand JL, Feron O: Hsp90 and caveolin are key targets for the proangiogenic nitric oxide-mediated effects of statins. Circ Res 2001;89:866-873

53 Wyatt AW, Steinert JR, Mann GE: Modulation of the L-arginine/nitric oxide signalling pathway in vascular endothelial cells. Biochem Soc Symp 2004:143-156.

-54 Freyberg S, Song YH, Muehlberg F, Alt E: Thrombin peptide (TP508) promotes adipose tissue-derived stem cell proliferation via PI3 kinase/Akt pathway. J Vasc Res 2009; 46:98-102.

55 Motley ED, Eguchi K, Patterson MM, Palmer PD, Suzuki H, Eguchi S: Mechanism of endothelial nitric oxide synthase phosphorylation and activation by thrombin. Hypertension 2007;49:577-583.

56 Thors B, Halldorsson H, Thorgeirsson G: Thrombin and histamine stimulate endothelial nitric-oxide synthase phosphorylation at Ser1177 via an AMPK mediated pathway independent of PI3K-Akt. FEBS Lett 2004;573:175-180.
77 Brem H, Tomic-Canic M: Cellular and molecular basis of wound healing in diabetes. J Clin Invest 2007;117:1219-1222.

58 Gallagher KA, Liu ZJ, Xiao M, Chen H, Goldstein LJ, Buerk DG, Nedeau A, Thom SR, Velazquez OC: Diabetic impairments in NO-mediated endothelial progenitor cell mobilization and homing are reversed by hyperoxia and SDF-1 $\alpha$. J Clin Invest 2007;117: 1249-1259.

59 Burrow JW, Koch JA, Chuang HH, Zhong W, Dean DD, Sylvia VL: Nitric oxide donors selectively reduce the expression of matrix metalloproteinases- 8 and -9 by human diabetic skin fibroblasts. J Surg Res 2007;140:90-98.

60 Lobmann R, Ambrosch A, Schultz G, Waldmann K, Schiweck S, Lehnert H: Expression of matrix-metalloproteinases and their inhibitors in the wounds of diabetic and nondiabetic patients. Diabetologia 2002;45: 1011-1016.

61 Veves A, Akbari CM, Primavera J, Donaghue VM, Zacharoulis D, Chrzan JS, DeGirolami U, LoGerfo FW, Freeman R: Endothelial dysfunction and the expression of endothelial nitric oxide synthetase in diabetic neuropathy, vascular disease, and foot ulceration. Diabetes 1998;47:457-463.
62 Masters KS, Leibovich SJ, Belem P, West JL, Poole-Warren LA: Effects of nitric oxide releasing poly(vinyl alcohol) hydrogel dressings on dermal wound healing in diabetic mice. Wound Repair Regen 2002;10:286294.

63 RayChaudhury A, Frischer H, Malik AB: Inhibition of endothelial cell proliferation and bFGF-induced phenotypic modulation by nitric oxide. J Cell Biochem 1996;63:125134.

64 Powell JA, Mohamed SN, Kerr JS, Mousa SA: Antiangiogenesis efficacy of nitric oxide donors. J Cell Biochem 2000;80:104-114.

65 Jones SG, Edwards R, Thomas DW: Inflammation and wound healing: the role of bacteria in the immuno-regulation of wound healing. Int J Low Extrem Wounds 2004;3: 201-208.

66 Bauer JA, Rao W, Smith DJ: Evaluation of linear polyethyleneimine/nitric oxide adduct on wound repair: therapy versus toxicity. Wound Repair Regen 1998;6:569-577. 